文】

\title{
数值計算による一様等方性乱流中の 沈降性粒子の拡散係数の検討
}

\author{
NUMERICAL STUDY ON DIFFUSION COEFFICIENT OF SETTLING \\ PARTICLES IN ISOTROPIC HOMOGENEOUS TURBULENCE
}

\author{
上田年比古* ・ 神 野 健 二** ・ 粐 井 和 朗*** ・ 前 浜 光 爾**** \\ By Toshihiko UEDA, Kenji JINNO, Kazurō MOMII and Köji MAEHAMA
}

\section{1. まえがき}

従来, 土木工学の分野では, 河川の浮遊砂あるいは沿 岸海域の浮遊漂砂などの濃度分布の研究，沈殿池の濁質 除去機構さらにまた近年環境問題の一環として貯水池の 濁水の清澄化過程の解明などが重要な課題となって多く の研究が行われている.これらは，主としてせん断乱流 の場における沈降性粒子についての問題であり，おもに 粒子濃度に関する抗散方程式によって解析が行われてい る. この場合, 式中の粒子の拡散係数には, 流体の拡散 係数（したがって近似的に流体の渦動粘性係数）を代用 したり，あるいはこれに補正の係数を乗じた值を用いて (る ${ }^{1)}$. しかしこれによって求めた粒子の濃度分布は 実測值とかなり相違することがあり ${ }^{3)}$ ，粒子の拡散係数 の値は不明確であることが指摘されている．次にまた粒 子の拡散係数を, 実測の濃度分布に合うょうに，拡散方 程式から逆算して求めて検討を行っているが5)，いまだ 粒子の拡散係数についての明確な結論は得られていない ようである.

一方, 一様乱流中の微細粒子の挙動については, これ まで工学上, 特に化学工学の分野での重要な課題として 数多くの研究が行われている. たとえば J.O. Hinze ${ }^{6), 7)}$ は一様乱流中の粒子運動の解析を行い流体と粒子との拡 散係数の相違などを究明し，また S. Yuu ら ${ }^{8)}$ は空気噴 流の乱れへの微細粒子の追従過程などを研究し, 乱流運 動と粒子運動との関係を検討している. しかしこれら は，非沈降性粒子を対象にしたものである.またこれま ではたとえ粒子に沈降性があってもそのために粒子の挔 散係数は変わるものではないとされていた．次に近年

\footnotetext{
* 正会員 工博 九州大学教授 工学部水工土木学科

** 正会員 工博 九州大学助教授 工学部水工士木学科

*** 正会員 農修 九州大学助手 工学部水工士木学科

**** 正会員 工修 清水建設株式会社
}

J.L. Lumley $^{9)}$ は，一様な水平速度をもつ乱流中に沈降 性粒子がある場合, 平均的に斜め下に沈降する粒子は, 鉛值方向に長い楕円形の分散をすることなどについて若 干の解析的説明を行って，沈降性粒子の拡散係数に異方 性があることを指摘している。

以上のことから，本報では，まず一様等方性乱流の場 を発生させ，その中にランダムに配置した粒子の運動方 程式の数值解を求める, いわゆる乱流中の沈降性粒子の 挙動に関する数值実験を行い，粒子の拡散係数を算定し 検討を行うことを試みた. これによって従来不明確であ った一様等方性乱流中の沈降性粒子の拡散係数について の検討を行った. これはまた土木工学の分野で問題とさ れているせん断乱流中の浮遊砂などの拡散係数に関する 一つの基礎的知見を得ようとするものである．なお乱流 場は Fourier 級数表現に基づいた S.A. Orszag and G.S. Patterson のスペクトル法 ${ }^{10)}$ を用いて 3 次元一様等 方性乱流場を算定し，また粒子の拡散係数は数值実験に よる方法と新たに提示した近似的方法により求めて検討 を加えている.

\section{2. 一様等方性乱流の数值計算 ${ }^{100,11)}$}

\section{（1）乱流場の基礎式}

非圧縮性流体に対する Navier-Stokes 方程式は，渦度 $\boldsymbol{w}=\boldsymbol{w}(\boldsymbol{x}, t)$, 運動エネルギー $E=(1 / 2) \boldsymbol{u} \cdot \boldsymbol{u}$ および $\boldsymbol{s}=$ $\boldsymbol{s}(\boldsymbol{x}, t)=\boldsymbol{u} \times \boldsymbol{w}$ を用いて次のように表わされる ${ }^{10)}$.

$$
\partial \boldsymbol{u} / \partial t-\nu \boldsymbol{\nabla}^{2} \boldsymbol{u}=\boldsymbol{s}-\boldsymbol{\nabla}\left(p / \rho_{f}+E\right)
$$

また連続の式は,

$$
\boldsymbol{\nabla} \cdot \boldsymbol{u}=0 \cdot \cdots
$$

ここに, $t$ : 時間, $\boldsymbol{\nabla}:$ ナブラ, $\boldsymbol{x}$ : ベクトル座標, $\nu$ : 動粘性俰数, $\rho_{f}$ : 流体密度, $\boldsymbol{u}=\boldsymbol{u}(\boldsymbol{x}, t)$ : 変動速度, $p$ $=p(\boldsymbol{x}, t)$ : 圧力である. ここで式 (1)，(2) の数值計算 にスペクトル法を用いることにする，いま一様等方性乱 
流場で変動速度 $\boldsymbol{u}(\boldsymbol{x}, t)$ が一辺 $l$ の立方体の境界上で周 期的境界条件を満足すると仮定すれば,

$$
\boldsymbol{u}(\boldsymbol{x}, t)=\sum_{\text {all } \boldsymbol{k}} \hat{\boldsymbol{u}}(\boldsymbol{k}, t) \exp (I \boldsymbol{k} \cdot \boldsymbol{x}) .
$$

のような Fourier 級数展開が可能となる.ここに，I： 虚数単位, $\boldsymbol{k}=2 \pi \boldsymbol{n} / l: 3$ 次元波数ベクトル, また $\boldsymbol{n}$ は, $-\infty<n_{i}<\infty$ ( $i$ は 3 次元の軸方向を示し, 1, 2, 3 の 值をとる) の整数べクトルである. 数值計算において整 数ベクトル $\boldsymbol{n}$ は有限個で打ち切らねばならないので, $n_{i}$ のとり得る值域を,

$$
-N / 2 \leq n_{i} \leq N / 2
$$

とする. $N^{3}$ は実空閒格子点の個数に対応する. 連続の 式（2）を考慮し式（1）の 2 回の curl をとると波数空 間において次式を得る.

$$
\begin{aligned}
& d \hat{\boldsymbol{u}} / d t+\nu k^{2} \hat{\boldsymbol{u}}=\hat{\boldsymbol{\tau}} \ldots \ldots . . \\
& \hat{\boldsymbol{\tau}}=-k^{-2}\{\boldsymbol{k} \times(\boldsymbol{k} \times \hat{\boldsymbol{s}})\}
\end{aligned}
$$

また波数空間における連続の式は,

$$
\boldsymbol{k} \cdot \hat{\boldsymbol{u}}=0
$$

である.ここに, $\hat{\boldsymbol{s}}=\hat{\boldsymbol{s}}(\boldsymbol{k}, t)$ は $\boldsymbol{s}(\boldsymbol{x}, t)$ の Fourier 変 換であり, 渦度 $\boldsymbol{w}(\boldsymbol{x}, t)$ は $\hat{\boldsymbol{w}}=I \boldsymbol{k} \times \hat{\boldsymbol{u}}$ の Fourier 逆変 换として求められる.

\section{（2）乱流場の数値計算}

式 (5) の左辺第 2 項の粘性項の $\hat{\boldsymbol{u}} \boldsymbol{k} \hat{\boldsymbol{u}}(\boldsymbol{k}, t+\Delta t)$ を 用いれば，波数空間に㧍ける Fourier 成分 $\hat{\boldsymbol{u}}(\boldsymbol{k}, t+\Delta t)$ を求める有限差分形は， $\Delta t$ を差分時間間隔とすれば,

$$
\boldsymbol{a}(\boldsymbol{k}, t+\Delta t)=\{\hat{\boldsymbol{u}}(\boldsymbol{k}, t)+\Delta t \hat{\boldsymbol{\tau}}(\boldsymbol{k}, t)\} /\left(1+\nu k^{2} \Delta t\right)
$$

この差分計算にあたって，まず初期乱れの場の Fourier 成分 $\hat{\boldsymbol{u}}(\boldsymbol{k}, 0)$ を次の 4 つの性質を満足するように正規 乱数を用いて発生させる ${ }^{12)}$.

(i ) 式（3）において $\boldsymbol{u}(\boldsymbol{x}, 0)$ は実数であり， $\hat{\boldsymbol{u}}(\boldsymbol{k}$, 0 ）は複素数であることから得られる共役条件

$$
\hat{\boldsymbol{u}}(\boldsymbol{k}, 0)=\hat{\boldsymbol{u}}^{*}(-\boldsymbol{k}, 0)
$$

ここに, * は共役複素数を示す.

(ii) 連続の式 (7)

（iii）異なる波数において

$$
\overline{\hat{u}_{i}(\boldsymbol{k}, 0) \hat{u}_{j}\left(\boldsymbol{k}^{\prime}, 0\right)}=0 \quad \boldsymbol{k} \neq-\boldsymbol{k}^{\prime} .
$$

ここに, 添字 $i$ および $j$ は 3 次元の軸方向を示し 1,2 , 3 の值をとる. また上付きバーは ensemble 平均を示す (以後も同じ意味とする).

(iv) $\hat{u}_{i}(k, 0)$ と $\hat{u}_{j}(-\boldsymbol{k}, 0)$ の積の ensemble 平均 は, 初期エネルギースペクトル $\hat{E}(k, 0)$ を用いて

$$
\overline{\hat{u}_{i}(\boldsymbol{k}, 0) \hat{u}_{j}(-\boldsymbol{k}, 0)}=2 \pi^{2}\left\{\hat{E}(k, 0) / k^{2}\right\} P_{\boldsymbol{i} j}(\boldsymbol{k})
$$

ここに, $k^{2}=k_{1}{ }^{2}+k_{2}{ }^{2}+k_{3}{ }^{2}, P_{i j}(\boldsymbol{k})=\delta_{i j}-k_{i} k_{j} / k^{2}, \delta_{i j}:$

Kronecker のデルタ $(i=j: 1, i \neq j: 0)$ を示す.

なお式 (11) の $\hat{E}(k, 0)$ には次の值を与えた. すな
わち数值計算を行う波数領域内の低波数領域と高波数領 域ではエネルギーが十分減衰していることが必要である ことから, U. Schumann ら ${ }^{100}$ に従って减衰終期におけ る熱伝導型エネルギースペクトル方程式の解と類似な $\hat{E}(k, 0)=A k^{4} \exp \left(-B k^{2}\right)$ の形を仮定し, この式の定 数 $A, B$ を, 時刻 $t=0$ における一様等方性乱流の乱れ 強度の 2 乗 $\overline{u^{2}(0)}$ が $\overline{u^{2}(0)}=(2 / 3) \int_{0}^{\infty} \hat{E}(k, 0) d k$ となる ことおよびエネルギーが最大となる波数を $k_{\text {peak }}$ とおく ことにより求めれば,

$$
\begin{aligned}
\hat{E}(k, 0)= & 16 \sqrt{2 / \pi} \overline{u^{2}(0)} k_{\text {peak }}{ }^{-5} k^{4} \\
& \cdot \exp \left\{-2\left(k / k_{\text {peak }}\right)^{2}\right\} \cdots
\end{aligned}
$$

となる. 以上の 4 条件により決定される $\hat{\boldsymbol{u}}(\boldsymbol{k}, 0)$ を初期 条件として，式（8）の差分計算を行う.

本報で数值計算を行った乱流場は, 一辺の長さ $l=2.0$ $\mathrm{cm}$ の立方体の実空間を計算領域とし, 全格子点数 $N^{3}=$ $32 \times 32 \times 32=32768$, 格子間隔約 $0.6 \mathrm{~mm}$ とした. また $\nu=0.013 \mathrm{~cm}^{2} / \mathrm{s}, \quad k_{\text {peak }}=4.775 \pi \mathrm{cm}^{-1}, \Delta t=0.005 \mathrm{~s}, \overline{u^{2}}$ $(0)=0.4225 \mathrm{~cm}^{2} / \mathrm{s}^{2}$ とし, 波数空間から実空間への変換 およびその逆の変換は, 高速 Fourier 変換 (FFT) を 用いて行った.

本報で用いたスペクトル法は, 実空間における乱流運 動を記述する方程式を Fourier 変換して数值解を得るシ ミュレーション法で, 波数空間での有限差分計算に伴う 誤差や高波数での打ち切り誤差を避けることはできない が，(1) 実空間における速度べクトル $\boldsymbol{u}(\boldsymbol{x}, t)$ の位置べ クトル $\boldsymbol{x}$ についての微分項が, 波数空間においては波 数べクトル $\boldsymbol{k}$ についての代数計算になり微分項の離散 化誤差が防げること, (2) Fourier 変換およびその逆変 換を高速 Fourier 変換で行うため数值計算時間を大幅 に短縮できることなどの利点をもちその有用性は高い ${ }^{13)}$ と考えられる.

\begin{tabular}{|c|c|c|c|c|c|}
\hline \multirow{2}{*}{  } & \multicolumn{3}{|c|}{ 各方向の乱れ強度 $(\mathrm{cm} / \mathrm{s})$} & \multirow{2}{*}{$\begin{array}{l}\text { ミ゙クロ } \\
\text { スケール } \\
\lambda(0)(\mathrm{cm})\end{array}$} & \multirow{2}{*}{$\begin{array}{l}\text { 渦の平均径 } \\
L(0)(\mathrm{cm})\end{array}$} \\
\hline & $x$ 方向 & $y$ 方向 & $z$ 方向 & & \\
\hline 0.643 & 0.636 & 0.654 & 0.638 & 0.132 & 0.165 \\
\hline
\end{tabular}

\section{（3）乱流場の数値計算結果と考察}

以上により模擬発生させた乱流場の初期場の諸特性量 は表一1のようになり, 初期乱れ強度の 2 乗は各方向に ほぼ等しい值となっていて, ミクロスケールスに基うくく 初期場の Reynolds 数は, $R e_{\lambda}=\sqrt{\overline{u^{2}(0)}} \lambda / \nu=6.5$ であ る. また数值シミュレーションの結果を用いてェネルギ ースペクトル，伝達スペクトルおよびミクロスケールな どの時間的変化および連続条件などの検討を行った結 果，本報で採用した $N$ および $\Delta t$ でほぼ妥当な一様等

\section{表一1 初期場の諸特性量}






図一1 流体の乱れ強度および積分特性距離の時間的変化

方性乱流場が得られていることを確認した. この詳細は 文献 11) に述べている.

数値計算の結果得られた流体場の乱れ強度の 2 乗 $\overline{u^{2}}$ $(t)$ および渦の平均径 $L(t)$ の時間的変化を 図一1に示 している. 渦の平均径はエネルギースペクトル $\hat{E}(k, t)$ を用いて次式により計算した。

$$
L(t)=\left\{\pi / 2 \overline{u^{2}}(t)\right\} \int_{0}^{\infty} \hat{E}(k, t) k^{-1} d k
$$

図一1によると, 渦の平均径は乱れ強度が時間的に減衰 する過程で，格子間隔（約 $0.6 \mathrm{~mm}$ ) の 3 倍程度から 10 倍程度のスケールまで増加していることがわかる.

なお，ここで得られた乱流場は，貯水池，沈殿池など の水域の清澄化過程のある時期拉よびある場所において 実際に存在する乱れと考えられ，ここで得られた乱流場 で沈降性粒子の拡散係数の特性の把握は十分可能と考え る. なお前述の計算の始めに与える $\overline{u^{2}(0)}$ をさらに大き くとって, 図一1 の值以上の乱れ強度をもつ乱流場の発 生を試みたが, 計算結果の精度の低下さらに解の発散を きたし乱流場の算定ができなかったことを付記する.

\section{3. 乱流中の粒子の拡散係数の数值実験による 算定}

\section{（1）粒子運動の数值計算}

3 次元一様等方性乱流中における単一球形粒子の運動 方程式として J.O. Hinze が提示している 式帛を参考に して次式を用いることにする.

$$
d v_{p, i} / d t=a\left(v_{f, i}-v_{p, i}\right)+b d v_{f, i} / d t+c \delta_{i 3}
$$

ここで,

$$
\begin{aligned}
& a=\frac{18 \nu}{\left(\rho_{p} / \rho_{f}+1 / 2\right) d^{2}}, \quad b=\frac{3 / 2}{\rho_{p} / \rho_{f}+1 / 2}, \\
& c=\frac{g_{r}\left(\rho_{p} / \rho_{f}-1\right)}{\rho_{p} / \rho_{f}+1 / 2} \ldots \ldots \ldots \ldots \ldots \ldots \ldots \ldots \ldots \ldots \ldots \ldots \ldots \ldots \ldots \ldots \ldots \ldots \ldots \ldots \ldots \\
&
\end{aligned}
$$

上式で, 座標方向を示す添字 $i$ は, $i=1,2$ を水平面 内の直交軸 $x, y$ とし， $i=3$ を鉛直下向きを十とする $z$ 軸とし, 以後も同様とする.また $v_{p, i}:$ 粒子速度, $v_{f, i}$ : 流体速度, $\rho_{p}$ : 粒子密度, $\rho_{f}$ : 流体密度, $d:$ 粒径, $\nu$ : 動粘性係数, $g_{r}$ : 重力加速度, $\delta_{i 3}: i=3$ のときのみ 1 となる Kronecker のデルタとする. 式 (14) の右辺の各 項は, 単位質量の粒子に働く力を示し, その第 1 項は, 粒 子と流体の相対速度による抵抗力でここでは，粒子とそ の近傍の流体との速度差を用いて計算される Reynolds 数は小さいと仮定して Stokes 則を用いている. 第 2 項 は流体の圧力勾配と仮想質量力から得られる項, 第 3 項 は重力に基づく項（重力から浮力を差し引いた值）であ る.なおこの式では, J.O. Hinze の提示した式中の Basset 項については，林ら ${ }^{14)}$ の研究を参考にして無視 し得ると仮定して除いている.

さて前章で得られた一辺 $l$ の立方体領域の一様等方性 乱流中にランダムに配置された粒子の運動を式 (14) の 数值積分により求めよう. 初期条件として ensemble 個 数 500 個の粒子 $\boldsymbol{A}$ の初期位置 $\boldsymbol{X}(\boldsymbol{A}, 0)$ を, 各方向ごと に一様乱数を用いて与え, この 500 個の異なる初期位置 での各粒子の初速度 $v_{p, i}[\boldsymbol{X}(\boldsymbol{A}, 0), 0]$ をその位置での 流体速度 $v_{f, i}[\boldsymbol{X}(\boldsymbol{A}, 0), 0]$ に等しいとおき ${ }^{15)}, v_{f, i}[\boldsymbol{X}$ $(\boldsymbol{A}, 0), 0]$ は前章の数值計算により得られた一様等方性 乱流場の速度 $u_{i}(\boldsymbol{x}, t)$ の 3 次元線形補間により求めた. 以上の初期条件から式 (14) を前進差分計算しおのおの の粒子を追跡した. この場合, 粒子の運動方程式の差分 時間間隔 $\Delta t$ は, 流体場の数值計算の場合と同一の 0.005 $\mathrm{s}$ とした. 式 (14) の差分計算の際に必要な粒子の移動 位置 $\boldsymbol{X}(\boldsymbol{A}, t)$ に打汁る流体速度 $v_{f, i}[\boldsymbol{X}(\boldsymbol{A}, t), t]$ は, 上述と同様に前章で得られた流体速度 $u_{i}(\boldsymbol{x}, t)$ の 3 次 元線形補間值を用いた. またここで用いた粒子運動算定 の乱流場は, 前述の一边 $l$ の立方体乱流領域が連続して 無限に存在するものと考え, 粒子がこの立方体領域の境 界を横切って移動しても同様な乱流域が 存在するとし て, 引き続き粒子の運動を追跡していった. なお数值計 算には, 表一2 に示寸比重 2.65 の 3 種類の粒径の粒子 を用いた.この粒径の範囲は細砂に属し, 貯水池あるい は沿岸海域 ${ }^{2}$ の懸濁物質として普通みうけられるもので ある。

次に本計算で用いた流体の初期乱れ強度は 図一1, 表 -1 に示すように小さい值のため, 流体と粒子の速度差

表一2 数值実験に用いた粒子

\begin{tabular}{c|c|c|c|c}
\hline 比重 & $\begin{array}{c}\text { 粒 径 } \\
d(\mathrm{~cm})\end{array}$ & $\begin{array}{c}\text { 終末沈降速度 } \\
\omega_{0}(\mathrm{~cm} / \mathrm{s})\end{array}$ & $\begin{array}{c}\text { Reynolds } \\
\omega_{0} d / \nu\end{array}$ & $\begin{array}{c}\text { 係数 } a \text { の逆数* } \\
1 / a(\mathrm{~s})\end{array}$ \\
\hline 2.65 & 0.015 & 1.56 & 1.79 & $3.0 \times 10^{-8}$ \\
$"$ & 0.020 & 2.76 & 4.25 & $5.4 \times 10^{-8}$ \\
$"$ & 0.025 & 4.32 & 8.31 & $8.4 \times 10^{-8}$ \\
\hline
\end{tabular}

* J.J. Riley らが与えたなじみ時間 
による Reynolds 数もたかだか 表一2 に示す $\omega_{0}$ によ る Reynolds 数程度と考えられ, Stokes 則がほぼ成立す る範囲と考えてよからう。

\section{（2） 粒子の拡散係数の数值実験による算定}

上述の粒子運動の数值計算結果を用いて粒子の拡散係 数を算定しよう.

いま $Y_{i}(t)$ を，時刻 $t$ におけるお扔ののの粒子の移動 位置 $X_{i}(\boldsymbol{A}, t)$ と 500 個の粒子の平均移動位置 $\overline{X_{i}(\boldsymbol{A}, t)}$ との差

$$
Y_{i}(t)=X_{i}(\boldsymbol{A}, t)-\overline{X_{i}(\boldsymbol{A}, t)}
$$

とすれば粒子の拡散係数 $D_{i}(t)$ は次式により計算され る.

$$
D_{i}(t)=(1 / 2) d \overline{Y_{i}{ }^{2}(t)} / d t
$$

図一2に 500 個の粒子の ensemble 個数を用い式 (16) から算定した方向別, 粒径別の粒子の拡散係数 $D_{i}(t)$ を 示している. また比較のため一様等方性乱流場の 500 個 の流体粒子を追跡し式（16）功計算される流体の搪散 係数を点線で示している. この図で粒子の拡散係数の時 間変化が波うっているが，これは粒子の個数を増やす か，あるいは，粒子の初期位置をあらためて，乱数によ り発生させて同様な計算を行い，これらの数多くの結果 の平均をとれば，平滑化されるものと考えられる.

図一2より粒子および流体とも拡散係数は始め時間と ともに増加して, 最大值に達し, その後徐々に減少して
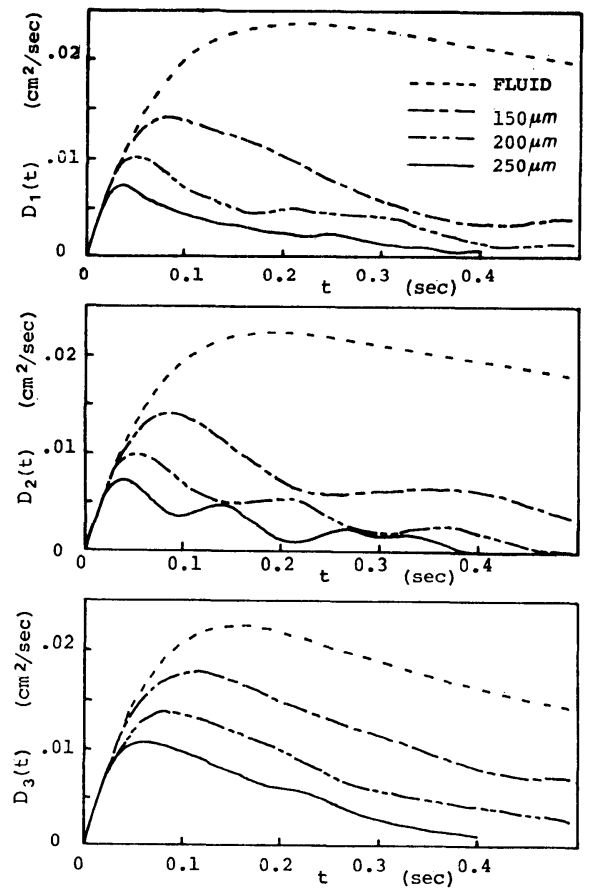

$D_{1}, D_{2}$ : 水平面内の直交蚰方向, $D_{8}:$ 鉛直粗方向 図一2 流体と粒子の拡散保数の時間变化
いくことがわかる.この減少は，図一1 に示すように流 体場の乱れ強度が時間とともに減衰しているためであ り，このことは，十分大きい拡散時間後には拡散保数は 一定となる一般の定常乱流場における拡散係数の時間的 変化とは異なっている．なお，流体についての拡散係数 は各方向についてほぼ同じ值が得られていて，これは一 様等方性乱流であることから肯定できる算定結果といえ よう. 次に粒子の拡散係数は，方向によりその大きさが 相違し， $D_{3}$ が $D_{1}, D_{2}$ に比べて大きな做を示している ことがわかる.

\section{4. 乱流中の粒子の拡散係数の速度相関による 解}

ここでは上述の数值実験から得られた沈降性粒子の拡 散係数の異方性について，さらに検討するために，粒子 の拡散係数の算定をできるだけ理論的面から行ってみよ う.

いま粒子 $\boldsymbol{A}$ が, 時刻 $t$ に $\boldsymbol{X}(\boldsymbol{A}, t)$ の位置にいたと して，その位置での粒子 $\boldsymbol{A}$ の $i$ 方向の変動速度 $v_{p, i^{\prime}}$ $[\boldsymbol{X}(\boldsymbol{A}, t), t]$ を $v_{p, i}{ }^{\prime}(t)$ と記すことにし，またその位置 での流体の $i$ 方向の変動速度 $v_{f, i}{ }^{\prime}[\boldsymbol{X}(\boldsymbol{A}, t), t]$ を $v_{f, i^{\prime}}$ ( $t$ ） と記すことにする. 次にこの粒子が $\tau$ 時間後に $X$ $(\boldsymbol{A}, t+\tau)$ の位置に移動したとして，その位置での粒子 $\boldsymbol{A}$ の $i$ 方向の変動速度 $v_{p, i}[\boldsymbol{X}(\boldsymbol{A}, t+\tau), t+\tau]$ を $v_{p, i^{\prime}}(t+\tau)$ と記し，その位置での流体の $i$ 方向の変動 速度を $v_{f, i}{ }^{\prime}(t+\tau)$ と記すことにすれば，これら 4 つの 変動速度に関する相関関数には次の 4 つが考えられる.

$$
\begin{aligned}
& R_{f f, i}(t, \tau)=\overline{v_{f, i}(t) v_{f, i}(t+\tau)} \\
& R_{f p, i}(t, \tau)=\overline{v_{f, i}{ }^{\prime}(t) v_{p, i}{ }^{\prime}(t+\tau)} \\
& R_{p f, i}(t, \tau)=\overline{v_{p, i}{ }^{\prime}(t) v_{f, i}{ }^{\prime}(t+\tau)} \\
& R_{p p, i}(t, \tau)=\overline{v_{p, i}{ }^{\prime}(t) v_{p, i}{ }^{\prime}(t+\tau)}
\end{aligned}
$$

なお式 (20) は，粒子の Lagrange 速度相関関数であ り，これを用いれば粒子の拡散係数 $D_{i}(t)$ は次式で表わ される.

$$
D_{i}(t)=\int_{0}^{t} R_{p p, i}(t, \tau) d \tau
$$

ここでは，流体の空間的相関関数から $R_{f f, i}(t, \tau)$ を 求める近似式を提示し, 次いで $R_{f f, i}(t, \tau)$ から $R_{p p, i}$ $(t, \tau)$ を求める速度相関についての関係式を誘導し, 式 (21) より粓子の拡散係数 $D_{i}(t)$ を求めることを試みよ う.

図一3 は, 粒子 $\boldsymbol{A}$ が時刻 $t$ にいた位置 $\boldsymbol{X}(\boldsymbol{A}, t)$ (図 の $\left.\boldsymbol{X}_{1}\right)$ における流体の変動速度の時間変化と, 粒子 $\boldsymbol{A}$ がそれから $\tau$ 時間後に移動した位置 $\boldsymbol{X}(\boldsymbol{A}, t+\tau)$ (図の $\left.X_{2}\right)$ における流体の変動速度の時間変化を示している. $P_{1}$ 点は粒子 $\boldsymbol{A}$ の時刻 $t$ での時空間位置, $Q_{2}$ 点は粒子 


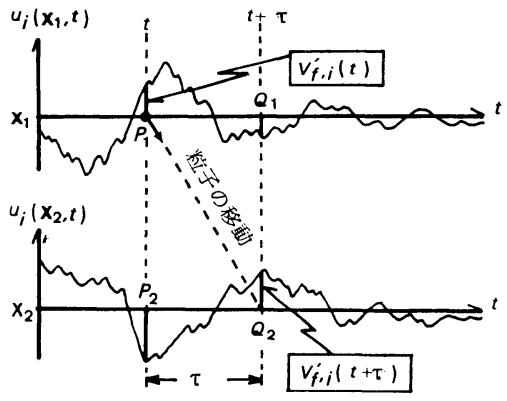

図一3 流体の速度相関の説明図

$\boldsymbol{A}$ の時刻 $t+\tau$ での時空間位置であり，したがって図示 のように $P_{1}$ 点, $Q_{2}$ 点の流体の変動速度はそれぞれ前 述の $v_{f, i}^{\prime}(t), v_{f, i}^{\prime}(t+\tau)$ となる、Wま粒子の平均移動 速度は, ensemble 平均的にみて鉛值方向に終末沈降速 度 $\omega_{0}$ と考えられる. したがって図一标にいて粒子の $\tau$ 時間後の平均移動距離 $\overline{\boldsymbol{X}(\boldsymbol{A}, t+\tau)-\boldsymbol{X}(\boldsymbol{A}, t)}$ は, 鉛 㨁方向に $\omega_{0} \tau$ となる. いま式 (17) の $R_{f f, i}(t, \tau)$ につ いて考えよう. 図一3 で時刻 $t$ を固定し鉛直方向に距離 $r=\omega_{0} \tau$ だけ離れた 2 点, $P_{1}, P_{2}$ の流体の変動速度の空 間的相関関数 $R_{i}(t, r)$ は, 横相関係数を $g(t, r)$, 縦相 関係数を $f(t, r)$, 乱れ強度の 2 乗を $\overline{u^{2}(t)}$ とすれば, 次 式で表わされる.

$$
\left.\begin{array}{ll}
R_{1}(t, \boldsymbol{r})=R_{2}(t, \boldsymbol{r}) & =\overline{u^{2}(t)} g(t, r) \\
R_{3}(t, \boldsymbol{r}) & =\overline{u^{2}(t)} f(t, r)
\end{array}\right\}
$$

ここで, $\overline{u^{2}(t)}, g(t, r), f(t, r)$ はともに時間的に変化 し, 図-3 で時刻 $t+\tau$ における $Q_{1}, Q_{2}$ 点の流体の変 動速度の空間的相関関数は， $P_{1}, P_{2}$ 点のそれとは異な り, 式 (22) で $t=t+\tau$ として与えられる.

また数值計算による乱流場について各時間 $t$ ごとに算 定された $R_{1,2}(t, r), R_{3}(t, r)$ を図一4 に示している. 周知のように $r>0$ で $f(t, r)>g(t, r)$ であることか ら, 各時間について相関 $R_{3}(t, r)$ が, 相関 $R_{1}(t, r)$, $R_{2}(t, r)$ より長い正の相関をもつこと（たとえば図一4 の a と $\mathrm{a}^{\prime}$ 線との比較), および $\overline{u^{2}(t)}$ は図一1 のよう に時間的に減少するので, 相関関数は時間的に減少して いる(たとえば $\mathrm{a}, \mathrm{b}, \mathrm{c}$ 線の比較).

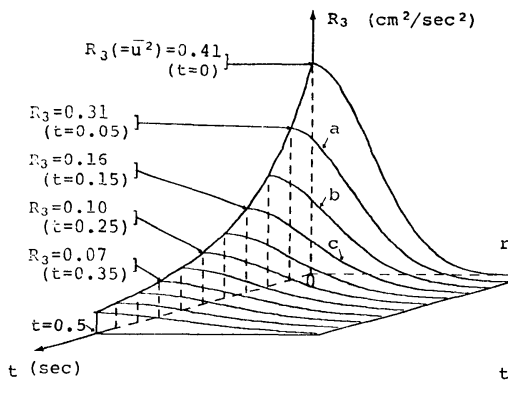

図一4 流体の空間的速度相関関数の時間的变化
さて本報では，いま求めようとする $P_{1}$ と $Q_{2}$ 点の流 体の変動速度 $v_{f, i}{ }^{\prime}$ の相関 $R_{f f, i}(t, \tau)$ を, 近似的に, 時刻 $t$ と $t+\tau$ におけるそれぞれの空間的相関関数 $R_{i}$ $(t, \boldsymbol{r})$ と $R_{i}(t+\tau, \boldsymbol{r})$ の平均值として与えることにし て, 式 (17) に示される $R_{f f, i}(t, \tau)$ を次のように近似 する.

$$
\begin{aligned}
& R_{f f, i}(t, \tau) \doteqdot(1 / 2)\left\{R_{i}(t, \boldsymbol{r})+R_{i}(t+\tau, \boldsymbol{r})\right\} \\
&=(1 / 2)\left\{\overline{u^{2}(t)} g\left(t, \omega_{0} \tau\right)\right. \\
&\left.+\overline{u^{2}(t+\tau)} g\left(t+\tau, \omega_{0} \tau\right)\right\} \\
&(i=1,2) \\
& R_{f f, 3}(t, \tau) \doteqdot(1 / 2)\left\{R_{3}(t, \boldsymbol{r})+R_{3}(t+\tau, \boldsymbol{r})\right\} \\
&=(1 / 2)\left\{\overline{u^{2}(t)} f\left(t, \omega_{0} \tau\right)\right. \\
&\left.+\overline{u^{2}(t+\tau)} f\left(t+\tau, \omega_{0} \tau\right)\right\}
\end{aligned}
$$

式 (23) の右辺の各項は, 流体の乱れがわかっていれ ば求められる値で，たとえば図一4が与えられていれば これから $R_{i}(t, \boldsymbol{r})$ は $\tau$, したがって $r\left(=\omega_{0} \tau\right)$ と $t$ と から求められる.

図一5 に, このようにして得られた式（23）による値 と数值実験による変動速度から值接求めた 図一3の $P_{1}$, $Q_{2}$ 点間の相関を示している。 これによると両者はほぼ よい一致を示している. 以上によって本報の粒径粒子の 範䎴では，相関 $R_{f f, i}(t, \tau)$ は流体の乱れに関する空間 的相関関数 $R_{i}(t, \boldsymbol{r})$, したがって乱れ強度と横および稀 の相関係数を用いて近似的に求めることができる.

次に $R_{f f, i}(t, \tau)$ から $R_{p p, i}(t, \tau)$ を求める関係式を 誘導しよう. 式 (14) の粒子の速度 $v_{p}$ を沈降速度と変 動速度 $v_{p}^{\prime}$ との和として表わし, 式 (14) を整理すると 粒子の変動速度に関する運動方程式は,

$$
\begin{aligned}
d v_{p, i}{ }^{\prime}(t) / d t= & a\left[v_{f, i}{ }^{\prime}(t)-v_{p, i}{ }^{\prime}(t)\right] \\
& +b d v_{f, i}(t) / d t \cdots \cdots \cdots
\end{aligned}
$$

となる

さて式 (24) は時刻 $t^{\prime}=t-\tau$ のときにも成立するので

$$
\begin{aligned}
d v_{p, i}{ }^{\prime}\left(t^{\prime}\right) / d t^{\prime}= & a\left[v_{f, i}{ }^{\prime}\left(t^{\prime}\right)-v_{p, i}{ }^{\prime}\left(t^{\prime}\right)\right] \\
& +b d v_{f, i}{ }^{\prime}\left(t^{\prime}\right) / d t^{\prime} \cdots \ldots \ldots . . .
\end{aligned}
$$

両辺に $v_{f, i}{ }^{\prime}(t)$ をかけて ensemble 平均をとれば

$\overline{v_{f, i}{ }^{\prime}(t) d v_{p, i}{ }^{\prime}\left(t^{\prime}\right) / d t^{\prime}}=a \overline{\left[v_{f, i}{ }^{\prime}(t) v_{f, i}{ }^{\prime}\left(t^{\prime}\right)\right.}$

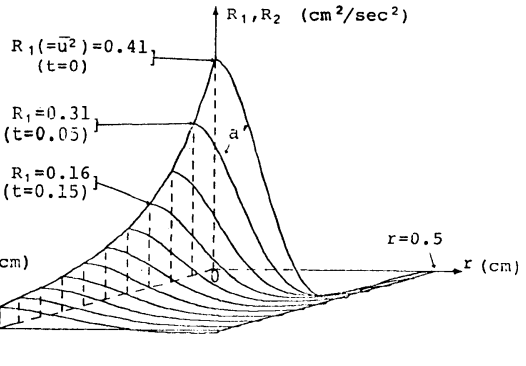



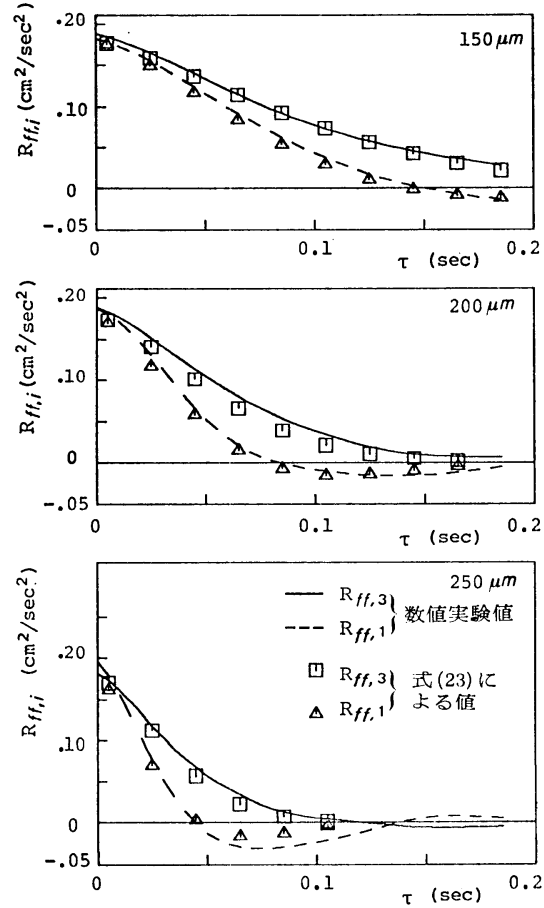

図一5 粒子の移動位置における流体速度の 相関関数 $(t=0.1 \mathrm{~s})$

$\left.-\overline{v_{f, i}{ }^{\prime}(t) v_{p, i}{ }^{\prime}\left(t^{\prime}\right)}\right]+\overline{b v_{f, i}^{\prime}(t) d v_{f, i}{ }^{\prime}\left(t^{\prime}\right) / d t^{\prime}}$

時刻 $t$ を固定し, 微分演算 $d / d t^{\prime}$ を $-\partial / \partial \tau$ に置き換 え，さらに式（17）と式（18）を用いれば，式（26）は 次式となる.

$$
\begin{aligned}
& \partial R_{f p, i}(t,-\tau) / \partial \tau=-a\left[R_{f f, i}(t,-\tau)\right. \\
& \left.\quad-R_{f p, i}(t,-\tau)\right]+b \partial R_{f f, i}(t,-\tau) / \partial \tau
\end{aligned}
$$

また

$$
\begin{aligned}
R_{f f, i}(t,-\tau) & =\overline{v_{f, i}{ }^{\prime}(t) v_{f, i}{ }^{\prime}(t-\tau)} \\
& =\overline{v_{f, i}{ }^{\prime}(t-\tau) v_{f, i}{ }^{\prime}(t)} \\
& =R_{f f, i}(t-\tau, \tau) \cdots \cdots
\end{aligned}
$$

ここに $R_{f f, i}(t-\tau, \tau)$ は, 式 (23) で $t=t-\tau$ として, $R_{f f, i}(t, \tau)$ と同様に, 流体の乱れ強度 と速度相関係数 から求められる.

次に式 (24) は時刻 $t^{\prime}=t+\tau$ のときにも成立するので 前述と同様にして, 両辺に $v_{p, i}{ }^{\prime}(t)$ をかけて ensemble 平均をとり整理すると次式となる.

$$
\begin{aligned}
\partial R_{p p, i}(t, \tau) / \partial \tau= & a\left[R_{p f, i}(t, \tau)-R_{p p, i}(t, \tau)\right] \\
& +b \partial R_{p f, i}(t, \tau) / \partial \tau \cdots \cdots(29)
\end{aligned}
$$

また

$$
\begin{aligned}
R_{p f, i}(t, \tau) & =\overline{v_{p, i}{ }^{\prime}(t)} \overline{v_{f, i}{ }^{\prime}(t+\tau)} \\
& =\overline{v_{f, i}{ }^{\prime}(t+\tau) v_{p, i}{ }^{\prime}(t)} \\
& =R_{f p, i}(t+\tau,-\tau) \cdots
\end{aligned}
$$

ここに $R_{f p, i}(t+\tau,-\tau)$ は式 (27), 式 (28) で $t=t+$ $\tau$ として前述と同様にして求められる.

以上によって, 粒子の Lagrange 速度相関 $R_{p p, i}(t$, て）を求めることができる.

なお式 (27) と式 (29) の差分解の算定に必要な相関 $R_{f p, i}(t, 0)$ および $R_{p p, i}(t, 0)$ には, 粒子の運動方程 式（14）の数值積分によって得られる粒子の変動速度の 積の ensemble 平均值 $\overline{v_{f, i}{ }^{\prime}(t) v_{p, i}{ }^{\prime}(t)}$ および $\overline{v_{p, i}{ }^{\prime}(t)}$ $\overline{v_{p, i}{ }^{\prime}(t)}$ を与えた. 図一6に時刻 $t=0.1 \mathrm{~s}$, 各粒径につ いて得られる $R_{p p, i}(t, \tau)$ の本解法による値と数值実験 による值とを示している. 両者は比較的よく一致してい るといえよう。

次にここで得られた $R_{p p, i}(t, \tau)$ を用いて式 (21) の 数值積分を行えば, 粒子の拡散倸数を算定することがで きる.いま粒径 $250 \mu \mathrm{m}$ の粒子について算定した結果を 図一7の各点に示している。 なお 図一7には比較のため
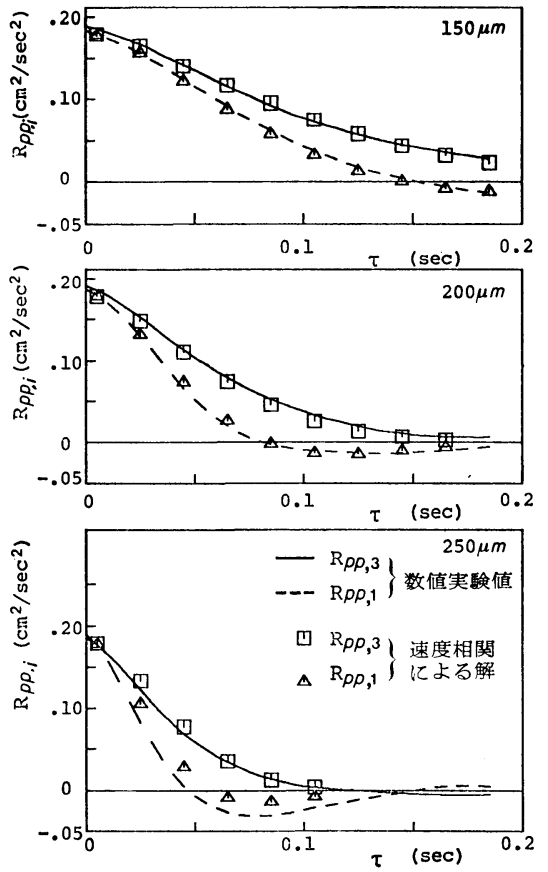

图一6 粒子の Lagrange 速度相関関数 $(t=0.1 \mathrm{~s})$

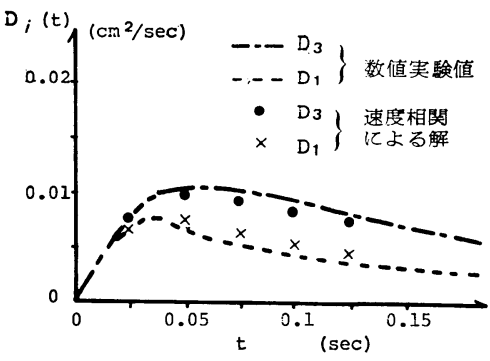

図一7 粒径 $250 \mu \mathrm{m}$ の粒子の扰散係数 
数值実験から直接求めた 図一2 の粒径 $250 \mu \mathrm{m}$ の拡散係 数 $D_{i}(t)$ を曲線で示している. 両者はほぼよい一致を 示している.

さて本章で述べた粒子の拡散係数の解析法は, 流体の 乱れ強度と速度相関係数 $[f(t, r), g(t, r)]$ および流体 と粒子に関する物理量（式 (27)，(29）の $a, b$ に含ま れる) さえ与えられれば, 式 (23)，(27)，(29)，(21)を 経て拡散係数が得られるもので, ここで新たに誘導した 式 (27) と式 (29) の速度相関関数に関する微分方程式 は簡単な式形で, その数值解は容易に求められるので, 前章の粒子の移動位置の追跡から算定する数值実験によ る法に比べ，その計算はかなり簡易化されると考えられ る. また 3. による算定結果は，あくまである一つの数 值実験結果であり，したがって前述したように図一2の 粒子の拡散係数の曲線が波うって算定されることも起こ り得ると考えられる. これに反し本解析法は乱れの場の 統計的性質をもとに理論的に導いたもので，算定結果は 普遍性をもつものと考えられる. また本解析法の誘導過 程は流体の乱れの特性が沈降性粒子の乱流拉散に与える 効果についての考察に役立つものと考えられ，たとえば 次章 5.（2）でもこれを利用している.

\section{5. 沈降性粒子の拡散係数についての考察}

数值実験から直接求めた抗散係数を示す図一2 および 図一7により次の 2 つの特徵的なことがわかる. すなわ ち,

（i ）本報で用いた粒径の範用では, 粒子の拡散係数 は, 粒径の減少とともに増大し, 流体の拡散係数に近づ くことが予想される.

（ii） 本報で用いた粒径の範讲では, 沈降性粒子の拡 散係数は異方性をもち,鉛直方向の拡散係数 $\left[D_{3}(t)\right]$ は, 水平方向のそれ $\left[D_{1}(t), D_{2}(t)\right]$ より大きな値となる. 以下これらについて考察しよう.

\section{（1）粒径小で拡散係数大となることについての考察}

これについては S. Yuu ら ${ }^{8)}$ の空気噴流における実験 結果と同一の傾向を示している.

粒径による抗散係数の相違の検討にあたっては，粒子 が流体の運動に追従する度合すなわち粒子の流体へのな じみの度合が問題となろう。この点に関して J.O. Hin$\mathrm{ze}^{7)}$ は，粒子の流体へのなじみ時間を取り上げ考察を加 えている.なじみ時間が小さくなるほど，粒子は流体に なじみやすく，したがって粒子の拡散係数は流体のそれ に近ゔくものと考えられる。このなじみ時間を J.J. Riley $ら^{15)}$ は, 式 (14), (15) に示す係数 $a$ の逆数 $1 / a(\mathrm{~s})$ で与えている.
いまなじみ時間と粒径との関係についてきわめて単純 な考察を加えてみよう. 式 (14) で左辺と右辺第 1 項を とりあげ 1 次元を考えると

$$
d v_{p} / d t=a\left(v_{f}-v_{p}\right)
$$

いま $t=0$ で $v_{p}=0$ として $v_{p}$ が $\kappa v_{f}$ になる時間 $T_{x}$ を求めると上式を積分して

$$
T_{\kappa}=(1 / a) \ln \{1 /(1-\kappa)\}
$$

すなわち, $T_{\kappa}$ は $1 / a$ に比例する. $T_{\kappa}$ はなじみ時間に 関連する值と考えられ，したがって $1 / a(s)$ はなじみ時 間に関連をもつ値といえよう. ちなみに J.J. Riley ら が与えたようになじみ時間を $1 / a$ とした場合は, $\ln \{1 /$ $(1-\kappa)\}=1$ すなわち $\kappa=0.63$ の場合となる. さて $1 / a$ は式 (15) から $d^{2}$ に比例している. したがって粒径が 小さくなるにつれてなじみ時間は小さくなり，したがっ て粒子の拡散係数は大となると考えられる. なお本報で 用いた粒子についての $1 / a(\mathrm{~s})$ を表一2 に示している.

\section{（2）鉊直方向の拡散係数が水平方向のそれより大と} なることの考察

これは J.L. Lumley が指摘した拡散係数の異方性と 同一の結果となっている. いま，これについて考察して みよう. まず, 前述 4. の拡散係数算定式の誘導過程か らみて異方性算出の 原因を考えると, 式 (22) から一 様等方性乱流場において $f(t, r)>g(t, r)$ のため, $R_{3}(t, r)>R_{1,2}(t, r)$ となり, 式 (23) から $R_{f f, 3}>$ $R_{f f, 1,2}$ が得られる. 次に式 (27)，(29）の厳密解が得 られないので $R_{p p, 3}$ と $R_{p p, 1,2}$ との大小関係を直接求 められないが, $R_{f f, 3}, R_{f f, 1,2}$ を入れた数值解の結果 $R_{p p, 3}>R_{p p, 1,2}$ となり, 式 (21) 加 $D_{3}(t)>D_{1,2}(t)$ となったものといえる. すなわちこの拡散係数の異方性 は $f(t, r)>g(t, r)$ に起因するといえよう.

次にこの異方性の原因を現象的に考えてみよう.

ここでは粒子の沈降速度は，流体の乱れ強度 $\sqrt{u^{2}}$ よ り十分大きく流体の渦を次々と脱出して沈降してゆくも のと考えよう. 前述のように本報で取り扱った粒子の終 末沈降速度 $\omega_{0}$ は表一2, 表一1, 図一1を比較してわ かるように $\sqrt{\overline{u^{2}}}$ より大きく上記の条件を満足している と考える.

いま粒子に働く外力として流体の乱れによる力を考え てみよう. 図-8について, 初めa 点にいた粒子が沈降

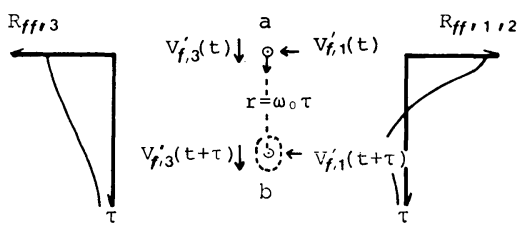

図一8 粒子の沈降過程説明図 
して $\tau$ 時間後に平均的に $\mathrm{b}$ 点にきたとする. また図の $R_{f f, 3}$ と $R_{f f, 1,2}$ はそれぞれ 粒子の始めの位置 $\mathrm{a}$ 点と 各沈降位置における粒子の沈降方向とそれに直角方向す なわち鉛直方向と水平方向の流体の速度相関である.こ こで, 式 (22), 式 (23) から $R_{f f, 3}$ と $R_{f f, 1,2}$ はそ れぞれ近似的に流体の綐速度相関係数 $f(t, r)$ および横 速度相関係数 $g(t, r)$ に比例し, $f(t, r)>g(t, r)$ であ ることから，図一4および 図一5 に示すように $r>0$ では $R_{f f, 3}>R_{f f, 1,2}$ となる.

さて, この $R_{f f, 3}, R_{f f, 1,2}$ は粒子が a 点から沈降す る間の各位置において, 粒子の受ける流体の乱れ速度に よる外力の相関に近似するものと考えることができよ う.したがって, 沈降する粒子が各沈降位置において, 流体から受ける力については, $R_{f f, 3}$ が $R_{f f, 1,2}$ より 長い正の相関をもつことから，a 点で受けた鉛直方向の 力の向きが，たとえば+であれば+方向の力を，またa 点でーのときは一の方向の力を比較的持続して受けなが ら沈降して $\mathrm{b}$ 点の上下に分散する. また $\mathrm{a}$ 点で受ける水 平方向の力の大きさと向きは, 比較的持続されず, した がって方向が,+ 一と変化する力を受けながら沈降して， $\mathrm{b}$ 点の左右に分散する.この結果粒子は $\tau$ 時間後, $\mathrm{b}$ 点 を中心として図の点線のように鉛直方向に長いほぼ棈円 形の範囲に分散するものと考えられる.このため一様等 方性乱流場における沈降性粒子の拡散係数は異方性をも ち，鉛直方向が水平方向より大きい値になると考えられ る.

\section{6. 結 び}

本報では，まず Fourier 級数表現によるスペクトル 法を用いて初期乱れ強度 $0.65 \mathrm{~cm} / \mathrm{s}$ の 3 次元一様等方性 乱流場を算定している.ここで用いたスペクトル法には 次のような利点が考えられる.

（1）実空間の速度の微分項が，波数空間では代数計 算になり, 微分項の離散化誤差が防げる.

(2) Fourier 変換およびその逆変換を高速 Fourier 変換で行うため演算時間を大幅に短縮できる.

次にこの乱流中の沈降性粒子の拡散係数を (1) Stokes 則の成立する範囲のもとでの粒径 $150 \mu \mathrm{m}, 200 \mu \mathrm{m}, 250$ $\mu \mathrm{m}$ の粒子の運動の数值実験結果からと, (2) 流体の速 度相関関数の近似式と新たに誘導した流体と粒子の速度 相関の関係式を用いた解法から算定し，(2) の有意性を 述べている.

次に以上求めた一様等方性乱流中を重力沈降する粒子 の搪散係数について, 次の知見を得ている.
（1）本報の粒径の範囲では, 粒子の拡散係数は粒径 の減少とともに増大する.

（2）沈降性粒子の挔散係数は異方性をもち，鉛直方 向が水平方向より大きい.

これは, 粒子の沈降方向の流体の変動速度成分の相関 が, 沈降方向に直角な方向の流体の変動速度成分の相関 より大きいことから $[r>0$ で流体の縱速度相関係数 $f$ $(t, r)>$ 流体の横速度相関俰数 $g(t, r)$ のため], 沈降方 向に, 粒子が流体から受ける力は, その大きさと向きが 比較的持続性をもち，また水平方向には，流体から受け る力の大きさと向きは比較的持続性をもたないため, 粒 子の位置は鉛直方向が水平方向より分散が大きくなるた めと述べている.

\section{参考文献}

1）椿東一郎：水理学 II, 森北出版, pp. 234 236, 1974 年.

2）堀川清司：海接厂学，東京大学出版会， pp. 218 224, 1981 年.

3）鮏川 登, ほか：浮流砂の堆積現象の数值解析, 第 26 回 水理講演会論文集, pp. 147 152, 1982 年 2 月.

4）粟谷陽一・藤崎一裕：開水路流れに打ける沈降性粒子ひ 平均移流速度と縦分散係数, 土木学会論文報告集, 第 311 号, pp. 71 79, 1981.

5）芦田和男・岡部健士：非平衡な浮遊砂浱度の算定法に関 寸る研究, 第 26 回水理講演会論文集, pp. 153 158, 1982 年 2 月.

6) Hinze, J.O. : Turbulence, MoGraw-Hill, pp. 352 364, 1959.

7) Hinze, J.O. : Turbulent fluid and particles interaction, Progress in Heat and Mass Transfer, Vol. 6, pp. 433 $\sim 452,1972$.

8) Yuu, S., et al. : Particle turbulent diffusion in a dust laden round jet, AIChE Jour., Vol. 24, No. 3, pp. 509 518, 1978.

9) Lumley, J.L. : Two-phase and non-Newtonian flows, Topics in Applied Physics, Vol. 12, Turbulence, Bradshaw, P. 編, Springer-Verlag, pp. 289 324, 1978.

10) Schumann, U. and G.S. Patterson : Numerical study of pressure and velocity fluctuations in neary isotropic turbulence, J. Fluid Mech., Vol. 88, Pt. 4, pp. 685 709, 1978.

11）上田年比古, ほか：一様等方性乱流の数值計算, 九州大 学工学集報, 第 55 巻, 第 1 号, pp. 17 24, 1982 年 1 月.

12) Orszag, S.A. : Numerical method for the simulation of turbulence, The Physics of Fluid Supplement II, pp. $250 \sim 257,1969$.

13）谷一郎: 流体力学の進歩・乱流, 丸善, pp. 166 167, 1980 年.

14）林 泰造・大橋正和：流体中を沈降する粒子の乱流特性 について, 第 24 回水理婰演会論文集, pp. 7 12, 1980 年 2 月.

15) Riley, J.J. and G.S. Patterson : Diffusion experiments with numerically integrated isotropic turbulence, The Physics of Fluids, Vol. 17, No. 2, pp. 292 297, 1974.

(1982.8.26 • 受付) 